\title{
Hubungan Book Tax Differences Terhadap Tax Avoidance Dengan Manajemen Laba Sebagai Variabel Moderasi
}

\author{
Dimas Prihandana Jati ${ }^{1}$, Etty Murwaningsari ${ }^{2}$ \\ 1,2 Universitas Trisakti, Jakarta, Indonesia
}

\section{INFO ARTIKEL JEL Classification :}

H26, M41

\section{Keywords :}

book tax difference, tax avoidance, earning management, fixed asset, intangible asset, sales growth, deferred tax expense, company size, leverage, profitability, roa, operational cash flow

\begin{abstract}
This research was conducted with the aim to examine the relationship between book tax with the tax avoidance. This study seeks to examine the items in the financial statements which are a proxy of the book tax difference that is closely related to the existence of indications of tax avoidance by the company. This study also uses moderation variables in the form of earnings management and control variables namely company size, leverage, profitability and operational cash flow. The sample selection is done by purposive sampling method with a total sample of 49 companies listed on the Indonesia Stock Exchange (BEI) in the time span between 2016 - 2018. Test results from this study indicate that fixed assets and intangible assets didn't have an effect towards tax avoidance. Sales growth have a positive effect on tax avoidance. Meanwhile deferred tax expense are known to have a negative effect on tax avoidance. The results of moderation of earnings management variables on 4 (four) independent variables in this study indicate that there is no significant probability value for the moderation of the four independent variables.
\end{abstract}

\begin{abstract}
ABSTRAK
Penelitian ini dilakukan dengan tujuan untuk menguji hubungan antara book tax dengan tax avoidance. Penelitian ini berupaya untuk menguji item-item dalam laporan keuangan yang merupakan proksi dari book tax difference yang berkaitan erat dengan adanya indikasi penghindaran pajak oleh perusahaan. Penelitian ini juga menggunakan variabel moderasi berupa variabel manajemen laba dan kontrol yaitu ukuran perusahaan, leverage, profitabilitas dan arus kas operasional. Pemilihan sampel dilakukan dengan metode purposive sampling dengan jumlah sampel 49 perusahaan yang terdaftar di Bursa Efek Indonesia (BEI) dalam rentang waktu antara tahun 2016 2018. Hasil penelitian ini menunjukkan bahwa aset tetap dan aset tidak berwujud tidak berpengaruh terhadap penghindaran pajak. Pertumbuhan penjualan berpengaruh positif terhadap penghindaran pajak. Sedangkan beban pajak tangguhan diketahui berpengaruh negatif terhadap penghindaran pajak. Hasil moderasi variabel manajemen laba pada 4 (empat) variabel independen dalam penelitian ini menunjukkan bahwa tidak adanya nilai probabilitas variabel yang signifikan untuk moderasi keempat variabel independen tersebut.
\end{abstract}




\section{Pendahuluan}

Sistem perpajakan di Indonesia sejak tahun 2007 telah menganut sistem selfassessment yang artinya Wajib Pajak berkewajiban menjalankan kewajiban perpajakan yang dimilikinya, seperti menghitung, melapor dan menyetor pajak, dilakukan sendiri secara benar. dengan sistem self assessment saat ini, maka Wajib Pajak-lah yang memegang kendali untuk mengambil inisiatif awal dalam pelaksanaan kewajiban perpajakannya dengan menghitung jumlah pajak yang harus dibayar lalu melakukan pembayaran serta kemudian melaporkan SPT Masa maupun SPT Tahunannya baik secara langsung ke KPP tempat wajib pajak terdaftar atau secara online.

Namun sebagaimana terafirmasi dalam benak banyak pihak bahwa membayar pajak bukanlah suatu hal yang dilakukan secara sukarela dan menyenangkan, sebagaimana diungkapkan oleh Listokin dan Schizer (2013) bahwa hanya segelintir orang yang dengan senang hati membayar pajak. Untuk itu dalam tugasnya mengamankan penerimaan negara, otoritas perpajakan diberikan berbagai wewenang untuk memastikan kebenaran pemenuhan kewajiban perpajakan para wajib pajak, salah satunya melalui pemeriksaan pajak.

Hal ini pula diperlukan mengingat beragam cara dilakukan wajib pajak dalam melakukan upaya penghindaran dari kewajiban pajaknya. Menurut James Kressler terdapat 2 (dua) macam penghindaran pajak yakni penghindaran pajak yang dibolehkan, dalam kata lain tidak melanggar batasan (Acceptable Tax Avoidance) dan penghindaran pajak yang yang tidak dibolehkan, dalam kata lain melanggar batasan (Unacceptable Tax Evasion). Penelitian ini berfokus pada perilaku penghindaran pajak yang diperbolehkan (tax avoidance) yang dilakukan dengan menggunakan celah-celah perbedaan peraturan dalam perpajakan dan akuntansi secara komersial.

Perbedaan penerapan aturan tersebut lebih jauh memunculkan book tax difference. Book tax differences sendiri merupakan manifestasi dari adanya perbedaaan temporer dan perbedaaan permanen. Perbedaaan temporer ini dapat terjadi diakibatkan oleh adanya perbedaaan waktu pengakuan penghasilan dan pengakuan beban antara laporan keuangan fiskal dengan laporan keuangan komersial, sementara perbedaaan permanen terjadi diakibatkan oleh adanya kebijakan yang berbeda yang diatur dalam standar akuntansi keuangan dengan peraturan di bidang perpajakan (Martani dan Persada, 2010).

Penggunaan variabel independen berupa book tax difference dalam penelitian ini diproksikan kepada empat variabel yaitu fixed asset, intangible asset, sales growth dan deferred tax assets. Penggunaan proksi variabel ini dilakukan dengan harapan untuk menemukan pos-pos mana di dalam laporan keuangan yang merupakan unsur-unsur pembentuk terciptanya book tax difference yang berpengaruh terhadap adanya indikasi perusahaan melakukan tax avoidance.

Kemudian juga digunakan variabel manajemen laba sebagai variabel moderasi dalam penelitian ini. Berdasarkan penelitian yang dilakukan oleh Sundvik (2017) yang dimuat dalam Nordic Tax Journal menyatakan bahwa perusahaan privat memiliki kecenderungan untuk melakukan manajemen laba dalam rangka menghadapi adanya perubahan tarif pajak yang akan berlaku. Sementara Lin et al. (2014) mengemukakan bahwa perusahaaan privat cenderung melakukan income shifting ketika akan terjadi penerapan tarif pajak yang lebih rendah dibanding tarif yang telah berlaku sebelumnya. Tang (2015) menjelaskan bahwa tingkat kesesuaian yang tinggi antara pelaporan keuangan secara akuntansi dan fiscal memiliki kaitan yang kuat dengan minimnya upaya manajemen laba dan penghindaran pajak yang dilakukan. Berdasarkan hal-hal tersebut dapat disimpulkan bahwa manajemen laba dilakukan dalam upaya perusahaan menghindari membayar pajak dengan benar dan dalam upaya meminimalisasi pembayaran pajak (Zommerman dan Goncharov, 2004). Dengan penggunaan variabel moderasi berupa manajemen laba tersebut diharapkan dapat memberikan kualitas hasil penelitian yang lebih baik dan komprehensif.

Disamping penggunaan variabel moderasi tersebut, penelitian ini juga dilakukan dengan menyertakan unsur variabel control demi menunjang kualitas hasil penelitian. Adapun variabel control yang penulis gunakan dalam 
penelitian ini adalah ukuran perusahaan, leverage, profitabilitas, dan operational cash flow. Berdasarkan penelitian yang dilakukan oleh Lanis dan Richardson (2012) dinyatakan bahwa ukuran perusahaan memiliki pengaruh positif terhadap tax avoidance. Kemudian leverage juga terbukti memiliki pengaruh positif terhadap tax avoidance mengacu kepada penelitian yang dilakukan oleh Dharma dan Ardiana (2016). Merle et al., (2019) juga menyatakan bahwa leverage berpengaruh positif terhadap transfer pricing yang biasa digunakan sebagai proksi tax avoidance. Variabel profitabilitas dipergunakan dalam rangka mengetahui seberapa besar kemampuan perusahaan dalam men-generate keuntungan. Menurut Darmawan dan Sukartha (2014) profitabilitas berpengaruh positif terhadap tax avoidance. Sementara itu perusahaan dengan arus kas operasional yang tinggi cenderung melakukan tax avoidance secara agresif (Kim dan Jang, 2018).

Keseluruhan hasil dari penlitian ini diharapkan dapat memberikan gambaran bagi regulator atau otoritas perpajakan di Indonesia untuk mengidentifikasi secara spesifik pospos di dalam laporan keuangan, yang menghasilkan laba fiskalnya berbeda dengan laba akuntansi (Book Tax Diffference), yang dapat mengindikasikan adanya upaya perusahaan melakukan penghindaran pajak. Poin yang juga menjadi perbedaan pada penelitian ini dibanding penelitian lainnya adalah digunakannya manajemen laba sebagai variable moderasi. Hal ini dikarenakan di dalam banyak penelitian manajemen laba sering ditempatkan sebagai variable independen maupun dependen alih-alih sebagai variabel moderasi.

\section{Telaah Teori dan Pengembangan Hipotesis}

\section{Teori Agensi}

Dalam menjalankan perusahaan umumnya para pemegang saham diwakili manajemen. Manajemen lah yang bertindak secara day to day untuk memastikan perusahaan beroperasi dengan baik dan optimal. Keadaan ini menggambarkan adanya hubungan antara pemegang saham (principal) dengan manajemen (agen) dengan tujuan untuk memperoleh keuntunggan serta memaksimalkan nilai kemakmuran perusahaan. Oleh karena itu diyakini manajemen yang memegang peranan penting dalam pengambilan keputusan (Desai dan Dharmapala, 2005) akan menjalankan perusahaan sebagaimana yang dikehendaki oleh pemegang saham (principal) yang telah mendelegasikan kewenangannya (Jensen dan Meckling, 1976). Namun dalam prakteknya hubungan ini seringkali memunculkan permasalahan, dimana manajemen mengambil keputusan atau kebijakan yang sifatnya berseberangan dengan kepentingan pemegang saham. Hal ini terjadi dikarenakan adanya asimetri informasi yaitu perbedaan tingkat informasi yang dimiliki oleh manajemen dengan pemegang saham. Hal ini juga ditegaskan oleh Jensen dan Meckling (1976) yang menyatakan bahwa Tindakan yang diambil manajemen (agen) tidak akan selalu berpihak untuk keuntungan pemilik karena memiliki kepentingannya sendiri.

\section{Book Tax Difference}

Book Tax Difference adalah selisih besaran yang muncul antara laba secara fiskal dengan laba menurut akuntansi (Tang, 2011). Book Tax Difference sering digunakan di dalam penelitian dalam rangka mengetahui pengaruhnya terhadap kualitas laba (persistensi laba) yang dilaporkan perusahaan di dalam laporan keuangannya atau dalam rangka untuk mengetahui apakah terdapat indikasi dilakukannya tindakan manajemen laba oleh manajemen perusahaan. Laba fiskal sendiri berdasarkan definisi yang terdapat di dalam PSAK Nomor 46 tentang Akuntansi Pajak Penghasilan adalah nilai laba atau keuntungan dalam satu periode yang dihitung berdasarkann peraturan perpajakan yang kemudian menjadi DPP PPh (dasar penghitungan pajak penghasilan). Dari pernyataan tersebut dapat terlihat bahwa yang menyebabkan perbedaaan antar laba fiskal dan laba akuntansi adalah adanya perbedaan konsep dan ketentuan dalam masing-masing sistem pelaporan baik secara fiskal atau secara akuntansi (Plesko, 2004). Perhitungan laba akuntansi mengacu kepada standar yang ditetapkan di dalam PSAK sementara laba fiskal mengacu kepada peraturan perpajakan dalam hal ini UU Nomor 36 Tahun 2008 tentang Pajak Penghasilan. Perbedaan 
peraturan ini memunculkan perbedaan yang dinamakan beda temporer dan beda permanen.

Menurut Formigoni et al. (2009) perbedaan permanen muncul karena adanya pengakuan terhadap biaya atau pendapatan dalam ketentuan akuntansi namun di sisi lain tidak diakui dalam secara fiskal. Perbedaan temporer sendiri dibagi 2 yaitu perbedaan waktu positive dan perbedaan waktu negative. Perbedaan waktu positive dapat dikatakan terjadi ketika ketentuan akuntansi mengakui beban lebih lambat daripada pengakuan beban berdasarkan ketentuan pajak. Perbedaan waktu positif juga terjadi ketika penghasilan untuk tujuan pajak diakui lebih lambat daripada penghasilan yang diakui menurut ketentuan akuntansi. Sementara itu perbedaan waktu negatif bertindak sebaliknya yaitu terjadi ketika ketentuan perpajakan mengakui beban lebih lambat daripada pengakuan beban dalam ketentuan akuntansi. Perbedaan waktu negatif juga terjadi apabila penghasilan diakui secara lebih lambat menurut akuntansi dibandingkan menurut ketentuan pajak.

\section{Manajemen Laba}

Manajemen laba adalah serangkaian tindakan yang diambil manajemen untuk memanipulasi nilai laba dengan memanfaatkan diskresi yang ada di dalam ketentuan akuntansi namun tetap sejalan dengan prinsip-prinsip di dalam standar akuntansi keuangan dan kemudian menggunakan diskresi tersebut untuk mendapatkan tingkat keuntungan yang diinginkan manajemen (Belkoui, 2017). Berdasarkan penelitian yang dilakukan oleh Healy (1985), Healy \& Wahlen (1999), Beneish (2001) dan (Scott, 2009) dinyatakan beberapa alasan yang mendasari tindakan manajemen melakukan manajemen laba. Alasan tersebut antara lain upaya windowdressing dalam rangka initial public offering (IPO), meningkatkan kompensasi yang diterima manajer sekaligus memberikan jaminan keamanan atas pekerjaan mereka, penghindaran pelanggaran kontrak pinjaman, menjaga ekspektasi para investor dan menjaga reputasi perusahaan, mengurangi regulatory cost atau meningkatkan regulatory benefit dalam tujuan perusahaan melakukan initial public offering (IPO). Terdapat ragam jenis pengukuran untuk menghitung manajemen laba diantaranya model modified Jones
(1995), model Healy (1985), Model DeAngelo (1986), model Kothari (2005), dan Stubben (2010).

\section{Tax Avoidance}

Menurut Rachmat Soemitro (1979) pajak sebagai iuran dari rakyat kepada negara memiliki sifat yang memaksa dan tidak mendapatkan imbal balik secara langsung. Namun walalupun karakter pajak memiliki sifat yang dapat dipaksakan atau wajib, tidak semua orang bersedia dengan sukarela menjalankan kewajiban perpajakannya dengan sebenar-benarnya. Berangkat dari hal tersebut maka banyak terjadi upaya penghindaran pajak yang dilakukan para wajib pajak. Menurut Slemrod (2014) penghindarann pajak dapat diartikan sebagai tindakan yag sifatnya legal, tidak melanggar aturan, yang tujuannya untuk mengurangi kewajiban pajak perusahaan. Sementara menurut Lim (2011) penghindaran pajak didefinisikan sebagai upaya penghematan pajak yang bersumber dari metode pengurangan pajak umum yang tingkat legalitas dari upaya meminimalkan kewajiban pajak tersebut masih dipertanyakan.

Annuar et al. (2014) menyampaikan bahwa keuntungan dari aksi penghindaran pajak yang dipraktekkan perusahaaan adalah adanya kas yang dapat dihemat atas kewajiban pajak yang terhindarkan. Menurut Bird dan Nozemack (2016) terdapat beberapa praktik tax avoidance yang selama ini dilakukan oleh perusahaan diantaranya inversi, manipulasi transfer pricing, dan penggunaan tax haven dalam tujuannya untuk memaksimalkan keuntungan.

\section{Pengembangan Hipotesis}

\section{Pengaruh Fixed Asset terhadap Tax Avoidance}

Beberapa cara dilakukan dalam upaya penghindaran pajak diantaranya dengan memanfaatkan perbedaan ketentuan fiscal dengan ketentuan berdasarkan PSAK. Salah satu yang menjadi perbedaan adalah terkait penyusutan (depresiasi) aktiva tetap baik dalam hal metode depresiasi maupun penentuan jangka waktu penyusutan. Mengacu kepada hal tersebut maka semakin banyak nilai aktiva tetap yang dimiliki perusahaan tentu akan memengaruhi 
perbedaan nilai penyusutan dalam hal metode yang digunakan secara akuntansi berbeda dari yang diperbolehkan dalam ketentuan fiscal yang menjadi salah satu celah pemanfaatan praktek tax avoidance. Hal ini selaras dengan pernyataan Kim dan Jeong (2006) yang mengemukakan bahwa ada kecenderungan perusahaan dengan nilai asset yang tinggi melakukaan tax avoidance. Kemudian berdasarkan hasil penelitiaan Acquah, P. (2017) dikemukakan bahwa tangible asset memiliki pengaruh terhadap tax avoidanc maka diyakini aktiva tetap berpengaruh terhadap terjadinya upaya tax avoidance.

$\mathrm{H}_{1}$ : Fixed Asset berpengaruh positif terhadap Tax Avoidance

\section{Pengaruh Intangible Asset tehadap Tax Avoidance}

Seringkali transaksi antar perusahaan umumnya akuisisi kepemilikan perusahaan menghasilkan suatu goodwill yang merupakan aktiva tidak berwujud namun memiliki nilai yang signifikan. Hal ini dipengaruhi antara lain karena nilai jual merek, kepercayaan konsumen atas kualitas produk merek, atau tingkat optimisme bahwa perusahaan dapat menghasilkan manfaat lebih di masa depan.

Seperti halnya pada aktiva tetap, perbedaan metode amortisasi dapat menghasilkan perbedaan nilai yang terlapor dalam Laporan Keuangan untuk tujuan Perpajakan atau Laporan Keuangan Perusahaan pada umumnya. Kim dan Im (2017) dalam penelitiannya menyatakan bahwa intensitas perusahaan dalam melakukan research \& development memiliki pengaruh terhadap tax avoidance. Seperti diketahui bahwa hasil dari kegiatan research $\&$ development biasanya berbentuk intangible asset. Oleh karena itu, diyakini bahwa besarnya nilai aktiva tidak berwujud dapat memengaruhi terjadinya tax avoidance.

$\mathrm{H}_{2}$ : Intangible Asset berpengaruh positif terhadap tax avoidance

\section{Pengaruh Sales Growth terhadap Tax Avoidance}

Besarnya pertumbuhan nilai penjualan pada umumnya akan berimplikasi lurus dengan pertumbuhan laba baik secara akuntansi maupun fiscal. Hal ini terjadi karena pada umumnya perusahaan telah menetapkan Net Profit Margin atas produk yang dijual. Namun pertumbuhan laba tersebut tidak lantas membuat orang dengan sukarela melaksanakan pemenuhan kewajiban perpajakannya secara benar.

Hal ini mengacu pada pernyataan Listokin dan Schizer (2013) bahwa hanya segelintir orang yang senang membayar pajak maka perusahaan akan melakukan upaya-upaya untuk meminimalisasi laba dalam rangka tax avoidance. Hal ini senada dengan pernyataan Kim dan Chae (2017) yang menyatakan sales growth memiliki pengaruh terhadap tax avoidance. Sehingga ketika nilai pertumbuhan penjualan tumbuh semakin besar maka begitu pula indikasi perusahaan melakukan tax avoidance semakin besar pula.

$\mathrm{H}_{3}$ : Sales Growth berpengaruh positif terhadap Tax Avoidance

\section{Pengaruh Deferred Tax Expense terhadap Tax Avoidance}

Adanya perbedaan temporer maupuan perbedaan permanen antara ketentuan fiskal dan akuntansi akan menghasilkan baik Bebaan Pajak Tangguhan atau Manfaaat Pajak Tangguhan. Bebaan Pajak Tangguhan terjadi ketika laba secara akuntansi nilainya lebih kecil dibanding nilai laba secara fiskal. Akibatnya tercipta beban pajak tangguhan yang menjadi kewajiban perusahaan untuk dibayarkan di periode berikutnya. Besarnya nilai beban pajak tangguhan yang muncul mengindikasikan pula banyaknya perbedaan cara yang dilakukan manajemen dalam mengelola transaksi-transaksi dalam perusahaannya antara yang diatur dalam ketentuan fiscal maupun yang diatur secara akuntansi.

Penelitian Plesko (2004) menunjukkan semakin tinggi selisih perbedaan yang terjadi antara labaa secara fiskal dan laba secara akuntansi menunjukkkan pula semakin luasnya discreti akuntansi yang dilakukan oleh perusahaan. Besarnya tingkat diskresi tersebut dapat terlihat pada bebaan pajak tangguhan yang mana dapat dipergunakan untuk mengetahui adanya indikasi penghindarann pajak. Hal tersebut turut mendorong keyakinan penulis bahwa bebaan pajak tangguhan berpengaruh terhadap tax avoidancee. 
$\mathrm{H}_{4}$ : Deferred Tax Expense berpengaruh positif terhadap Tax Avoidance

\section{Manajemen Laba dalam pengaruhnya} antara Fixed Asset terhadap Tax Avoidance

Pemanfaatan aktiva tetap dalam tujuannya untuk memperkecil beban pajak dapat dilakukan dengan memperpanjang masa manfaat aktiva tetap atau memperbanyak jumlah kepemilikan aktiva tetap. Aktivitas tersebut yang dilakukan dalam rangka manajemen laba dapat memperbesar beban depresiasi periode berjalan sehingga meminimalisasi laba fiskal yang berdampak pada berkurangnya beban pajak yang dibayarkan kepada negara. Penggunaan unsur depresiasi aktiva tetap sebagai bagian manajemen laba juga dijelaskan oleh Zmijewski dan Hagerman (1981). Dengan moderasi dari variabel manajemen laba, yang menurut Acquah (2017) berpengaruh terhadap terjadinya tax avoidance, maka diyakini manajemen laba memperkuat pengaruh dari fixed asset terhadap tax avoidance.

$\mathrm{H}_{5}$ : Manajemen Laba memperkuat terjadinya pengaruh antara fixed asset terhadap tax avoidance

\section{Manajemen Laba dalam pengaruhnya antara Intangible Asset terhadap Tax Avoidance}

Salah satu yang sering menjadi perhatian pada aktiva tidak berwujud adalah bagaimana menentukan penilaian terbaik dalam menemukan nilai aktiva tidak berwujud secara tepat. Tentu ada berbagai pandangan dalam menilai aktiva tidak berwujud dikarenakan melibatkan unsur pandangan subjektif.

Keyakinan seseorang atas nilai aktiva tidak berwujud bisa berbeda dengan pandangan orang lain. Peran manajemen laba dalam hal ini di antaranya dapat dilakukan dengan meningkatkan nilai aktiva tidak berwujud sehingga akan memperbesar beban amortisasinya. Hal ini dapat terjadi dan sulit untuk diketahui sepanjang fiskus tidak melakukan uji kewajaran atas nilai aktiva tidak berwujud yang biasanya hanya dilakukan saat adanya pemeriksaan wajib pajak. Fungsi manajemen laba dalam kaitannya dengan tax avoidance diyakini terjadi berdasarkan penelitian yang dilakukan oleh Desai dan Dharmapala (2009). Sejalan dengan hal tersebut maka diyakini manajemen laba dapat memperkuat terjadinya pengaruh antara intangible asset terhadap tax avoidance. $\mathrm{H}_{6}$ : Manajemen Laba memperkuat terjadinya pengaruh antara intangible asset terhadap tax avoidance

\section{Manajemen Laba dalam pengaruhnya antara Sales Growth terhadap Tax Avoidance}

Tumbuhnya tingkat penjualan seringkali menjadi ukuran keberhasilan manajemen dalam mengelola perusahaan. Dalam penyusunan rencana dan anggaran kerja, pertumbuhan penjualan senantiasa menjadi prioritas dalam memproyeksikan target pendapatan di masa mendatang. Sejalan dengan hal tersebut, bertumbuhnya penjualan pada akhirnya juga akan meningkatkan kemakmuran para pemilik perusahaan. Berkaitan dengan teori agensi dimana memungkinkan terjadinya asimetri informasi antara manajemen dengan pemilik perusahaan. Harapan manajemen untuk mendapatkan insentif atas kinerja dapat mendorong dilakukannya manajemen laba untuk memaksimalkan pendapatannya yang salah satunya juga dilakukan dengan cara mengurangi beban pajak yang harus dibayar.

Sehingga ketika penjualan meningkat yang seharusnya berimplikasi pada meningkatnya beban pajak yang harus dibayar maka di sisi lain manajemen terpacu untuk mencari cara memasukkan unsur biaya-biaya tambahan guna meminimalisasi laba fiskal dan beban pajak. Tindakan ini tentunya meliputi manajemen laba dengan tujuan meminimalisasi jumlah pajak yang dbayar perusahaan. Berdasarkan penelitian Desai dan Dharmapala (2009) yang meyakini bahwa tindakan tax avoidance berasal dari tindakan manipulatif laporan keuangan dalam kegiatan manajemen laba. Penulis meyakini bahwa manajemen laba memperkuat terjadinya pengaruh antara sales growth terhadap tax avoidance.

$\mathrm{H}_{7}$ : Manajemen Laba memperkuat terjadinya pengaruh antara Sales Growth terhadap Tax Avoidance

Manajemen Laba dalam pengaruhnya antara Deferred Tax Epense terhadap Tax Avoidance 
Metode income shifting umum digunakan dalam upaya perusahaan melakukan manajemen laba. Hal ini melibatkan adanya perbedaan temporer yang terjadi antara ketentuan secara fiscal dan secara akuntansi. Sundvik (2017) dalam penelitiannya mengungkapkan adanya upaya perusahaan melakukan manajemen laba guna merespons penurunan tarif pajak. Hal yang lazim dilakukan dalam keadaan tersebut adalah income shifting dimana perusahaan menempatkan laba fiscal yang lebih besar pada saat tarif pajak menjadi lebih rendah sehingga tercipta keuntungan bagi perusahaan. Peristiwa ini dalam prosesnya memunculkan beban pajak tangguhan.

Oleh karena itu, adanya beban pajak tangguhan diyakini merupakan indikasi terjadinya tax avoidance. Dengan moderasi dari variabel manajemen laba yang menurut Sheckleford dan Shevlin (2001) yang menjelaskan bahwa perusahaan cenderung melakukan income shifting sebagai bagian dari srategi penghindaran pajak maka diyakini manajemen laba memperkuat pengaruh dari deferred tax expense terhadap tax avoidance.

$\mathrm{H}_{8}$ : Manajemen Laba memperkuat pengaruh antara Deferred Tax Expense terhadap Tax Avoidance

\section{Metode Penelitian}

Penelitian ini menggunakan sampel perusahaan industri manufaktur yang minimal telah terdaftar pada Bursa Efek Indonesia sejak 1 Januari 2015. Periode penelitian dilakukan dalam rentang 2016 - 2018 . Adapun metode pemilihan sampel menggunakan metode purposive sampling dengan kriteria bahwa perusahaan memiliki seluruh item variabel yang akan diuji dalam penelitian ini, khususnya intangible asset, serta dengan mengecualikan data outlier.

Metode pengukuran terhadap Fixed Asset yang digunakan adalah mengacu pada pendekatan yang dilakukan menggunakan referensi peneilitian Boubaker dan Dridi (2016), diukur dengan mengambil perubahan besaran nilai kotor aktiva tetap (gross PPE) yang dimiliki perusahaan antara tahun observasi dengan tahun sebelumnya dan kemudian dibagi dengan nilai gross PPE tahun sebelumnya. Model lebih lengkap disajikan sebagai berikut :

$$
\triangle P P E=\frac{P P E i, t-P P E i, t-1}{P P E i, t-1}
$$

$\triangle P P E \quad$ : besar perubahan nilai gross PPE antara periode saat ini (tahun observasi) dengan tahun sebelumnya

PPE i,t : Nilai gross PPE dalam tahun berjalan (observasi)

PPE i,t-1 : Nilai gross PPE dalam tahun sebelumnya

Intangible Asset dalam penelitian ini diukur dengan mengambil referensi dari penelitian Boubaker dan Dridi (2016) yang menggunakan nilai perubahan antara goodwill pada periode saat ini dibandingkan goodwill pada periode sebelumnya. Untuk menangkap gambaran determinan book tax difference secara lebih luas maka dilakukan sedikit modifikasi pada pengukuran yang sebelumnya dilakukan Boubaker dan Dridi (2016) yaitu memperluas nilai yang diambil bukan hanya goodwill tapi keseluruhan intangible asset yang dimiliki perusahaan. Model lebih lengkap disajikan sebagai berikut:

$$
\Delta I N T=\frac{I N T i, t-I N T i, t-1}{I N T i, t-1}
$$

$\Delta I N T: \begin{aligned} & \text { besar perubahan nilai gross } \\ & \text { intangible asset antara } \\ & \text { periode saat ini dengan } \\ & \text { periode sebelumnya }\end{aligned}$
INT i,t $: \begin{aligned} & \text { Nilai gross intangible asset } \\ & \text { pada periode saat ini (tahun } \\ & \text { observasi) }\end{aligned}$
INT i,t-1 : $\begin{aligned} & \text { Nilai gross intangible asset } \\ & \text { pada periode sebelumnya }\end{aligned}$

Dalam mengukur sales growth, digunakan referensi dari penelitian yang dilakukan oleh Tang (2017) yang mengkalkulasi selisih nilai penjualan periode saat ini dengan periode sebelumnya dan kemudian dibagi dengan nilai penjualan periode sebelumnya. Model lebih legkap disajikan sebagai berikut :

$$
\begin{array}{cl}
\triangle S A L E S= & \frac{S A L E S i, t-S A L E S i, t-1}{S A L E S i, t-1} \\
\triangle S A L E S: \begin{array}{l}
\text { besar perubahan nilai penjualan } \\
\text { antara periode saat ini dengan } \\
\text { periode sebelumnya }
\end{array}
\end{array}
$$


SALES i,t : Nilai penjualan pada periode saat ini

SALES i,t-1 : Nilai penjualan pada periode sebelumnya

Adapun metode pengukuran deferred tax expense (beban pajak tangguhan) dalam penelitian ini dilakukan dengan mengambil referensi pada penelitian Rachmawati (2010) dan Warsono (2017) yaitu dengan membagi nilai beban pajak tangguhan dengan total asset pada periode sebelumnya.

$$
\begin{aligned}
& \text { DTE } i, t=\frac{\text { Beban Pajak Tangguhan } i, t}{\text { TA } i, t-1} \\
& \text { DTE i,t : Deferred tax expense } \\
& \text { perusahaan } \\
& \text { Beban Pajak : Nilai beban pajak } \\
& \text { Tangguhan i,t tangguhan yang tersaji } \\
& \text { di dalam Laporan Laba } \\
& \text { Rugi perusahaan } \\
& \text { periode saat ini } \\
& \text { TA i,t-1 : Total asset perusahaan } \\
& \text { periode sebelumnya }
\end{aligned}
$$

Kemudian terkait dengan variabel dependen, di dalam penelitian ini digunakan variabel tax avoidance sebagai variable dependen dengan tujuan untuk memetakan unsur-unsur atau pos-pos di dalam laporan keuangan yang berpengaruh pada indikasi tindak penghindaran pajak yang dapat merugikan penerimaan negara melalui pajak. Metode pengukuran nilai tax avoidance yang digunakan di dalam penelitian ini adalah menggunakan Current ETR (CETR) sebagaimana mengacu pada penelitian yang dilakukan oleh Murwaningsari dan Ahnan (2019).

$$
\text { CETR } i, t=\frac{\text { Pajak kini } i, t}{\text { PTBI } i, t}
$$

$\begin{array}{cl}\text { CETRi,t : } & \text { Current Effective Tax Ratio } \\ & \text { digunakan sebagai proksi } \\ & \text { untuk menghitung adanya } \\ & \text { upaya Tax Avoidance oleh } \\ & \text { perusahaan }\end{array}$

Pajak kini : Beban pajak kini yang $\mathrm{i}, \mathrm{t}$ dikeluarkan perusahaan pada periode saat ini (tahun observasi)

PTBI i,t : Pre-tax before income yaitu nilai laba bersih sebelum pajak pada periode saat ini
Selain penggunaan variabel independen dan variabel dependen, penelitian ini juga menggunakan variabel moderasi berupa Manajemen Laba. Definisi dari manajemen laba adalah serangkaian tindakan yang dilakukan oleh manajemen untuk memanipulasi nilai laba dengan memanfaatkan diskresi yang ada di dalam ketentuan akuntansi namun tetap sejalan dengan prinsip-prinsip di dalam standar akuntansi keuangan dan kemudian menggunakan diskresi tersebut untuk mencapai tingkat keuntungan yang diharapkan oleh manajemen (Belkoui, 2017). Metode yang digunakan dalam menghitung nilai Manajemen Laba menggunakan teori perhitungan Stubben (2010) dengan metode conditional revenue model.

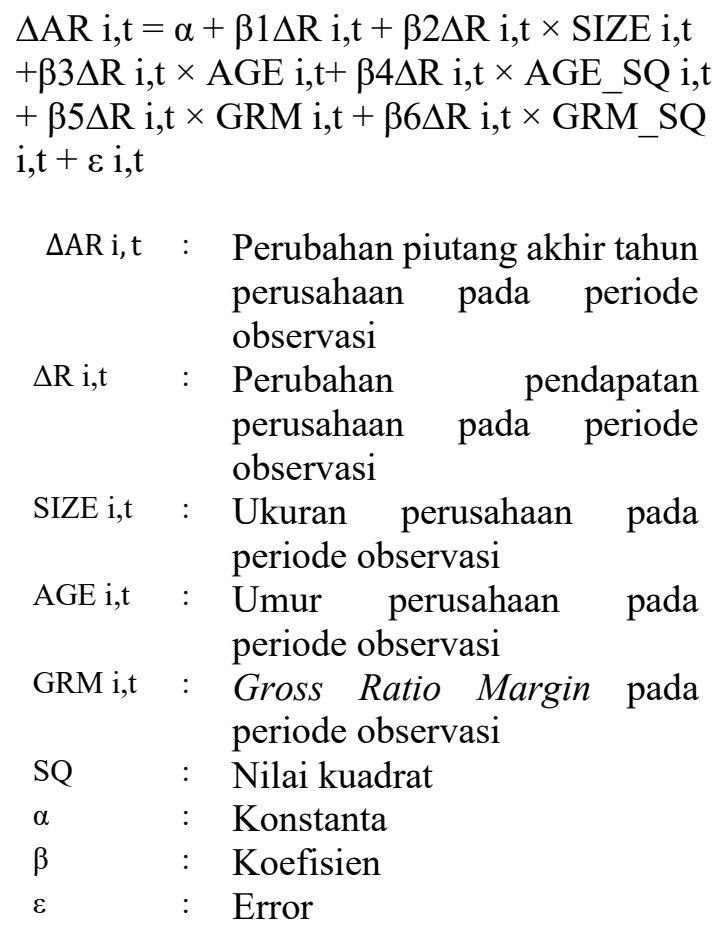

Salah satu variabel kontrol yang digunakan dalam penelitian ini adalah nilai uuran perusahaan yagn mana diukur dengan menggunakan nilai log natural dari nilai total aset yang dimiliki perusahaan sebagaimana yang juga dilakukan oleh Hung et al pada tahun 2018.

$$
\text { Sz i,t }=\text { Ln TA i,t }
$$

Szi,t : Ukuran perusahaan pada periode observasi 


\section{Ln TA i,t : Log natural dari nilai total asset pada periode observasi}

Kemudian variabel kontrol berikutnya adalah leverage yang dalam penelitian ini diukur dengan menggunakan metode perhitungan Debt to Asset Ratio dalam mengukur leverage sebagaimana juga dilakukan oleh Ahnan dan Murwaningsari, 2019.

$$
\text { LEV } i, t=\frac{\text { Liabilities } i, t}{T A i, t}
$$

LEV i,t : Leverage perusahaan pad periode observasi

Liabilities i,t : Total Liabilitas perusaha pada periode observasi

TA i,t : Total Assets perusahaa pada periode observasi

\begin{tabular}{llr}
\multicolumn{1}{c}{ Profitabilitas } & \multicolumn{1}{c}{ merupakan } & ukuran \\
kemampuan & perusahaan & dalam \\
menghasilkan & pendapatan & dengan
\end{tabular}
menggunakan sumber daya yang dimiliki baik aktiva maupun ekuitas perusahaan. Penelitian ini mengukur nilai profitabilitas dengan menggunakan perbandingan Return on Assets (ROA) sebagaimana juga telah dilakukan sebelumnya oleh Koouba dan Jarboui (2017).

$$
R O A i, t=\frac{P B T i, t}{A v g . T A i, t}
$$

ROA i,t : Return on Assets perusahaan pada periode observasi

PBT i,t : Profit before taxes; pendapatan sebelum dikurangi pajak periode observasi

Avg. : Average Total Assets pada TA i,t periode observasi; nilai total asset awal tahun ditambah total asset akhir tahun dibagi dua

Operational Cash Flow adalah kas yang dihasilkan dari dilakukannya kegiatan operasi perusahaan yang berkaitan dengan penerimaan kas, pengeluaran kas, pendapatan dan biaya-biaya. Aliran kas ini menggambarkan bagaimana kinerja perusahaan dalam mendapatkan keuntungan dan kemudian mengubahny menjadi kas. Variabel operational cash flow diukur dengan mengambil nilai arus kas operasi pada Laporan Arus Kas milik perusahaan (Ahnan dan Murwaningsari, 2019).

\section{Hasil Penelitian dan Pembahasan}

Penelitian ini menggunakan data panel sehigga dalam pengujiannya diperlukan pemilihan model regresi yang direkomendasikan terlebih dahulu. Dengan penggunaan variabel moderasi maka dilakukan uji persamaan regresi yang sebanyak 2 kali, dimana persamaan 1 hanya melibatkan variabel independent, variabel dependent dan variabel control. Sementara itu pada persamaan 2 melibatkan seluruh variabel termasuk variabel moderasi. Berdasarkan uji model pemilihan regresi dihasilkan rekomendasi penggunaan model yaitu persamaan 1 menggunakan Fixed Effect Model sementara pada persamaan 2 digunakan model Random Effect Model. Hasil pengujian lebih lengkap dapat dilihat pada table berikut :

Tabel 1 Pemilihan Model Regresi Persamaan 1

\begin{tabular}{|c|l|r|r|c|}
\hline No & Test & $\begin{array}{c}\text { Common } \\
\text { Effect }\end{array}$ & $\begin{array}{c}\text { Fixed } \\
\text { Effect }\end{array}$ & $\begin{array}{c}\text { Random } \\
\text { Effect }\end{array}$ \\
\hline 1 & Uji Chow & $\mathrm{x}$ & $\mathrm{v}$ & - \\
\hline 2 & $\begin{array}{l}\text { Uji } \\
\text { Hausman }\end{array}$ & - & $\mathrm{v}$ & $\mathrm{X}$ \\
\hline 3 & Uji LM & \multicolumn{3}{|c|}{ Tidak dilakukan } \\
\hline 4 & $\begin{array}{l}\text { Model } \\
\text { digunakan }\end{array}$ & - & $\mathrm{v}$ & - \\
\hline
\end{tabular}

Sumber : Diolah dari hasil pengujian menggunakan aplikasi Eviews 9

Tabel 2 Pemilihan Model Regresi Persamaan 2

\begin{tabular}{|l|l|c|c|c|}
\hline No & \multicolumn{1}{|c|}{ Test } & $\begin{array}{c}\text { Common } \\
\text { Effect }\end{array}$ & $\begin{array}{c}\text { Fixed } \\
\text { Effect }\end{array}$ & $\begin{array}{c}\text { Random } \\
\text { Effect }\end{array}$ \\
\hline 1 & Uji Chow & $\mathrm{x}$ & $\mathrm{V}$ & - \\
\hline 2 & $\begin{array}{l}\text { Uji } \\
\text { Hausman }\end{array}$ & - & $\mathrm{x}$ & $\mathrm{v}$ \\
\hline 3 & $\begin{array}{l}\text { Uji } \\
\text { Lagrange } \\
\text { Multipler }\end{array}$ & $\mathrm{x}$ & - & $\mathrm{v}$ \\
\hline 4 & $\begin{array}{l}\text { Model } \\
\text { digunakan }\end{array}$ & - & - & $\mathrm{v}$ \\
\hline
\end{tabular}

Sumber : Diolah dari hasil pengujian menggunakan aplikasi Eviews 9 


\section{Uji Regresi Data Panel}

\section{Analisis Regresi Persamaan 1}

Bentuk dari persamaan ini sebagai berikut.

TAXAV $=0,990269+0,062709 \Delta \mathrm{PPE}-$

$0,000357 \Delta \mathrm{INT}+0,077463 \quad \Delta$ SALES -

1,917991 DTE - 0,043705 Sz - 0,224590 LEV -

$0,254786 \mathrm{RoA}+2,75 \mathrm{e}-09 \mathrm{CFO}+\varepsilon$

Hasil uji Goodness of Fit atau uji koefisien determinasi pada persamaan ini menunjukkan nilai Adjusted R-Squared 0,988625 . Hal ini dapat diartikan bahwa variabel independent dapat menjelaskan $98,86 \%$ variasi yang muncul pada variabel dependen dengan melibatkan variabel kontrol.

Sementara hasil uji signifikansi simultan (Uji-F) menunjukkan hasil Prob (F-statistik) adalah 0,000000 . Hasil ini berada di bawah nilai $\alpha$ yaitu 0,05 . Dengan demikian dapat dikatakan seluruh variabel independen dan kontrol dalam model secara simultan berpengaruh terhadap tax avoidance.

Adapun uji signifikansi parsial (Uji t) menunjukkan hasil sebagai berikut.

Tabel 1. Hasil Uji t Persamaan 1

\begin{tabular}{|l|c|c|c|l|}
\hline \multicolumn{1}{|c|}{ Var. } & Coef. & Prob. & $\alpha$ & Hasil Sig. \\
\hline PPE & 0,062709 & 0,1010 & 0,05 & $\begin{array}{l}\text { Tidak } \\
\text { Signifikan }\end{array}$ \\
\hline INT & $-0,000357$ & 0,8960 & 0,05 & $\begin{array}{l}\text { Tidak } \\
\text { Signifikan }\end{array}$ \\
\hline $\begin{array}{l}\text { SALE } \\
\text { S }\end{array}$ & 0,077463 & 0,0003 & 0,05 & Signifikan \\
\hline DTE & $-1,917991$ & 0,0027 & 0,05 & Signifikan \\
\hline ROA & $-0,254786$ & 0,0004 & 0,05 & Signifikan \\
\hline LEV & $-0,224590$ & 0,0000 & 0,05 & Signifikan \\
\hline SZ & $-0,043705$ & 0,0150 & 0,05 & Signifikan \\
\hline CFO & $2,75 E-09$ & 0,1016 & 0,05 & $\begin{array}{l}\text { Tidak } \\
\text { Signifikan }\end{array}$ \\
\hline
\end{tabular}

Sumber : Hasil output Eviews versi 9

\section{Analisis Regresi Persamaan 2}

Persamaan regresi 2 ini dilakukan dengan menggunakan metode Random Effect Model dengan coef.covariant pada White (diagonal). Bentuk dari persamaan ini sebagai berikut.
TAXAV $=0,425959+0,132815 \Delta \mathrm{PPE}-$

$0,001648 \Delta \mathrm{INT}+0,198926 \Delta \mathrm{SALES}-$

4,361302 DTE - 3,60E-8 $\triangle$ PPE*EM -

2,22E-08 $\Delta \mathrm{INT} * \mathrm{EM}+3,96 \mathrm{E}-07$

$\triangle$ SALES*EM - 3,73E-07 DTE*EM - 0,

$016773 \mathrm{Sz}-0,056325 \mathrm{LEV}+0,288683 \mathrm{RoA}$

\section{$+3,87 \mathrm{E}-09 \mathrm{CFO}$}

Hasil uji Goodness of Fit atau uji koefisien determinasi pada persamaan ini menunjukkan nilai Adjusted $R$-squared 0,103006 . Hal ini dapat diartikan bahwa variabel independent hanya dapat menjelaskan $10,3 \%$ varian variabel dependen yang mungkin muncul dengan melibatkan variabel kontrol dan variabel moderasi.

Sementara hasil uji signifikansi simultan (Uji-F) menunjukkan hasil Prob (F-statistik) adalah 0,008906. Hasil ini berada di bawah nilai $\alpha$ yaitu 0,05 . Dengan demikian dapat dikatakan seluruh variabel independen dan kontrol dalam model secara simultan berpengaruh terhadap tax avoidance.

Adapun uji signifikansi parsial (Uji t) untuk menunjukkan hasil sebagai berikut.

Tabel 2. Hasil Uji t Persamaan 2

\begin{tabular}{|l|l|l|l|l|}
\hline \multicolumn{1}{|c|}{ Var. } & \multicolumn{1}{|c|}{ Coef. } & Prob. & $\alpha$ & \multicolumn{1}{|c|}{ Hasil Sig. } \\
\hline PPE & 0.132815 & 0.2573 & 0,05 & $\begin{array}{l}\text { Tidak } \\
\text { Signifikan }\end{array}$ \\
\hline INT & -0.001648 & 0.8797 & 0,05 & $\begin{array}{l}\text { Tidak } \\
\text { Signifikan }\end{array}$ \\
\hline SALES & 0.198926 & 0.0898 & 0,05 & $\begin{array}{l}\text { Tidak } \\
\text { Signifikan }\end{array}$ \\
\hline DTE & -4.361302 & 0.0358 & 0,05 & Signifikan \\
\hline ROA & 0.288683 & 0.0925 & 0,05 & $\begin{array}{l}\text { Tidak } \\
\text { Signifikan }\end{array}$ \\
\hline LEV & -0.056325 & 0.0225 & 0,05 & Signifikan \\
\hline SZ & -0.016773 & 0.2945 & 0,05 & $\begin{array}{l}\text { Tidak } \\
\text { Signifikan }\end{array}$ \\
\hline $\begin{array}{l}\text { CFO } \\
\text { SF- }\end{array}$ & $3.87 \mathrm{E}-09$ & 0.5331 & 0,05 & $\begin{array}{l}\text { Tidak } \\
\text { Signifikan }\end{array}$ \\
\hline $\begin{array}{l}\Delta \text { PPE*E } \\
\text { M }\end{array}$ & $-3.60 \mathrm{E}-08$ & 0.9408 & 0,05 & $\begin{array}{l}\text { Tidak } \\
\text { Signifikan }\end{array}$ \\
\hline $\begin{array}{l}\Delta \text { INT*E } \\
\text { M }\end{array}$ & $-2.22 \mathrm{E}-08$ & 0.6372 & 0,05 & $\begin{array}{l}\text { Tidak } \\
\text { Signifikan }\end{array}$ \\
\hline $\begin{array}{l}\Delta \text { SALES } \\
\text { *EM }\end{array}$ & $3.96 \mathrm{E}-07$ & 0.3579 & 0,05 & $\begin{array}{l}\text { Tidak } \\
\text { Signifikan }\end{array}$ \\
\hline $\begin{array}{l}\text { DTE*E } \\
\text { M }\end{array}$ & $-3.73 \mathrm{E}-07$ & 0.9224 & 0,05 & $\begin{array}{l}\text { Tidak } \\
\text { Signifikan }\end{array}$ \\
\hline
\end{tabular}

Sumber : Hasil output Eviews versi 9 


\section{Pembahasan Hasil Penelitian}

\section{Pengaruh fixed aset terhadap tax avoidance}

Berdasarkan hasil uji t diketahui pengaruh fixed asset terhadap tax avoidance menunjukkan nilai koefisien sebesar 0,062709 dengan nilai Prob. sebesar 0,1010. Nilai Prob. tersebut lebih besar dari nilai $\alpha(0,05)$ sehingga dapat dikatakan arah prediksinya bersifat positif namun tidak signifikan.

Hubungan positif antara fixed asset dengan tax avoidance pernah dikemukakan sebelumnya oleh Acquah, P. (2017) yang mengatakan bahwa fixed asset memiliki pengaruh yang sifatnya positif terhadap tax avoidance. Hal ini juga senada dengan hasil penelitian Kim dan Jeong (2006) yang memyatakan bahwa perusahaan yang memiliki nilai asset yang besar memiliki kecenderungan untuk melakukan tax avoidance.

Pernyataan ini dapat didasari dengan adanya kemungkinan bahwa perusahaan menerapkan metode depresiasi secara fiskal yang berbeda dengan metode yang diterapkan secara akuntansi yang pada akhirnya memunculkan book tax difference dan menjadi salah satu celah pemanfaatan praktik tax avoidance. Namun sifat signifikansi yang ditunjukkan bersifat tidak signifikan sehingga dimungkinkan bahwa perusahaan manufaktur yang menjadi sampel penelitian melakukan metode depresiasi yang tidak jauh berbeda penerapan secara akuntansinya dengan ketentuan perpajakan yang mengatur. Untuk itu dikarenakan sifat pengaruh fixed asset terhadap tax avoidance tidak signifikan maka hipotesa $\mathrm{H}_{1}$ pada penelitian ini dinyatakan ditolak.

\section{Pengaruh intangible asset terhadap tax avoidance}

Berdasarkan hasil uji t pada persamaan 1 sebelumnya diketahui bahwa pengaruh intangible asset terhadap tax avoidance memiliki nilai koefisien -0,062709 dengan nilai Prob. sebesar 0,8960. Nilai Prob. tersebut lebih besar dari nilai $\alpha(0,05)$ sehingga dapat dikatakan pengaruhnya bersifat negative dan tidak signifikan.

Hal ini sejalan dengan hasil penelitian Merle et al. (2019) dimana dikemukakan bahwa intangible asset berpengaruh negative terhadap transfer pricing dimana transfer pricing sendiri seringkali digunakan sebagai proksi dari tax avoidance.

Berdasarkan pengamatan penulis ketika menyusun sampel penelitian ditemukan bahwa banyak perusahaan yang tidak memasukkan unsur amortisasi dalam perbedaan temporer kewajiban perpajkaannya melainkan hanya memasukkan unsur penyusutan saja. Hal ini tentunya dapat menjadi jawaban atas tidak signifikannya pengaruh intangible asset terhadap tax avoidance. Selain itu terbatasnya jumlah perusahaan manufaktur yang mengakui kepemilikan intangible asset dalam laporan keuangannya pun turut menyumbang pengaruh atas hasil pengujian ini. Dengan demikian hipotesis $\mathrm{H}_{2}$ dinyatakan ditolak.

\section{Pengaruh antara variabel sales growth terhadap variabel tax avoidance}

Berdasarkan hasil uji $t$ persamaan 1 sebelumnya diketahui pengaruh antara variabel sales growth terhadap variabel tax avoidance memiliki nilai koefisien 0,077463 dengan nilai Prob. sebesar 0,0003. Nilai Prob. yang lebih kecil dari nilai $\alpha(0,05)$ dan nilai koefisien yang positif menunjukkan bahwa pengaruhnya bersifat positif signifikan.

Pernyataan ini pula memiliki kesamaan dengan hasil penelitian yang dikemukakan oleh Kim dan Chae (2017) yang menyampaikan bahwa sales growth berpengaruh secara positif terhadap tax avoidance. Sales growth atau pertumbuhan penjualan secara umum akan berimplikasi pada meningkatnya keuntungan yang diraih perusahaan. Kenaikan pada nilai penjualan yang dibukukan perusahaan biasanya diikuti pula dengan biaya operasional maupun harga pokok penjualan atau produksi yang diakui oleh perusahaan. Hal ini berbanding lurus dikarenakan untuk menjual lebih banyak maka perusahaan membutuhkan effort yang lebih besar sehingga secara langsung akan meningkatkan pula biaya operasional maupaun harga pokok produksi / penjualan.

Ketentuan di dalam pasal 6 dan pasal 9 UU nomor 36 Tahun 2008 mengatur mengenai biaya yang boleh dan tidak boleh dikurangkan dari penghasilan bruto. Perlu dicermati lebih jauh mengenai biaya-biaya yang dijadikan pengurang penghasilan oleh perusahaan apakah dapat digolongkan sebagai 
pengurang penghasilan bruto atau tidak. Hal ini dapat menjadi salah satu loop hole yang dapat dimanfaatkan oleh perusahaan dalam menerapkan praktik tax avoidance. Untuk itu $\mathrm{H}_{3}$ dinyatakan diterima.

\section{Pengaruh deferred tax expense terhadap tax avoidance}

Berdasarkan hasil uji t pada persamaan 1 sebelumnya diketahui pengaruh deferred tax expense terhadap tax avoidance memiliki koefisien sebesar -1,917991 dengan nilai Prob. 0,0027. Nilai Prob. tersebut lebih kecil dari nilai $\alpha(0,05)$ sehingga dapat dikatakan pengaruhnya bersifat negative signifikan. Hal ini senada dengan pernyataan Suandy (2008) dan Meiza, R (2015) yang melalui hasil penelitiannya menyatakan bahwa deferred tax expense berpengaruh negative terhadap tax avoidance.

Pernyataan tersebut dapat dipahami dikarenakan deferred tax expense mengartikan bahwa jumlah kewajiban pajak yang dibayarkan dengan kas oleh perusahaan secara fiscal lebih besar dibandingkan dengan yang diakui secara komersial pada laporan keuangan. Hal ini berarti perusahaan sangat memenuhi compliance atas kewajiban perpajakannya. Makna dari pengaruh negative tersebut berimbas pada deferred tax income atau manfaat pajak tangguhan yang merupakan kebalikan dari deferred tax expense atau beban pajak tangguhan.

Berdasarkan hasil penelitian ini maka dapat disimpulkan pula bahwa semakin besar nilai deferred tax income (manfaat pajak tangguhan) maka indikasi perusahaan melakukan tax avoidance semakin besar. Dengan demikian hipotesa $\mathrm{H}_{4}$ dinyatakan ditolak.

\section{Manajemen laba dalam pengaruhnya antara fixed aset, intangible asset, sales growth dan deferred tax expense terhadap tax avoidance}

Hasil moderasi manajemen laba (EM i,t) dengan variabel fixed aset (PPE $\mathrm{i}, \mathrm{t}$ ) memiliki nilai koefisien -3.60E-08 dan nilai Prob. 0.9408. Nilai Prob. tersebut lebih besar daripada nilai $\alpha$ yaitu 0,05 . Hasil moderasi manajemen laba (EM i,t) dengan variabel intangible asset (INT $\mathrm{i}, \mathrm{t})$ memiliki nilai koefisien -2.22E-08 dan nilai Prob. 0.6372.
Nilai Prob. tersebut lebih besar dari nilai $\alpha$ yaitu 0,05 . Hasil moderasi manajemen laba (EM i,t) dengan variabel sales growth (SALES i,t) memiliki nilai koefisien 3,96E-07 dan nilai Prob. 0,3579. Nilai Prob. tersebut lebih besar daripada nilai $\alpha$ yaitu 0,05 . Hasil moderasi manajemen laba (EM i,t) dengan variabel deferred tax expense (DTE $\mathrm{i}, \mathrm{t}$ ) memiliki nilai koefisien -3.73E-07 dan nilai Prob. 0,9224. Nilai Prob. tersebut lebih besar daripada nilai $\alpha$ yaitu 0,05 .

Berdasarkan hasil pengujian tersebut diketahui tidak terdapat hasil moderasi manajemen laba dengan tiap variabel independent yang memiliki nilai signifikan karena nilai Prob. berada di atas nilai signifikansi $(0,05)$. Hasil ini mengindikasikan bahwa variabel manajemen laba tidak dapat memoderasi pengaruh antara fixed asset, intangible asset, sales growth dan deferred tax expense terhadap indikasi adanya tax avoidance yang dipraktekkan perusahaan.

Penggunaan variabel moderasi memang memunculkan banyak resiko dikarenakan interaksi antar variabel yang jumlahnya banyak. Salah satunya terjadi dalam penelitian ini dimana manajemen laba yang diperoleh dari nilai residu hasil analisis regresi persamaan menggunakan metode conditional revenue model (Stubben, 2010) ternyata tidak dapat memoderasi hubungan antara variabel independent dalam penelitian ini dengan variabel dependennya. Selain itu berdasarkan hasil uji goodness of fit persamaan 1 (tanpa melibatkan variabel moderasi) diketahui nilai Adj. R-squared sebesar 98,86\% yang mana menunjukkan hasil yang sangat tinggi bahwa variabel-variabel yang digunakan pada model penelitian ini sudah menjelaskan hampir seluruhnya terhadap variabel dependen yang digunakan. Sehingga berdasar hal tersebut pula keberadaan manajemen laba sebagai variabel moderasi tidak begitu diperlukan dan sekaligus mementahkan hipotesis yang dikemukakan oleh penulis pada awal bagian penelitian. Untuk itu hipotesis $\mathrm{H}_{5}, \mathrm{H}_{6}, \mathrm{H}_{7}$ dan $\mathrm{H}_{8}$ dinyatakan ditolak.

\section{Kesimpulan, Keterbatasan, dan Implikasi Hasil Penelitian}

Fixed asset yang pada penelitian ini menggunakan nilai perubahan atas nilai gross PPE dari tahun ke tahun berdasarkan hasil pengujian diketahui tidak berpengaruh 
signifikan terhadap tax avoidance. Intangible asset yang pada penelitian ini menggunakan nilai perubahan atas nilai gross intangible asset baik dalam bentuk goodwill maupun asset tak berwujud lainnya dari tahun ke tahun berdasarkan hasil pengujian diketahui tidak berpengaruh signifikan terhadap tax avoidance.

Sales growth yang pada penelitian ini menggunakan nilai perubahan atas niai penjualan bersih yang berhasil dibukukan perusahaan dari satu periode ke periode berikutnya. Berdasarkan hasil pengujian diketahui variabel sales growth berpengaruh secara positif terhadap tax avoidance. Beban pajak tangguhan (deferred tax expense) yang pada penelitian ini didapatkan dari nilai beban pajak tangguhan dibagi dengan nilai pendapatan sebelum pajaknya, berdasarkan hasil pengujian diketahui bahwa deferred tax expense berpengaruh secara negatif terhadap tax avoidance.

Penggunaan manajemen laba sebagai variabel moderasi pada penelitian ini ternyata tidak membawa pengaruh signifikan terhadap pengaruh variabel independent baik fixed asset, intangible asset, sales growth dan deferred tax expense terhadap variabel dependen yaitu tax avoidance. Sehingga dapat dikatakan manajemen laba tidak dapat memoderasi pengaruh antara variabel independent terhadap variabel dependen.

Dalam penyusunan penelitian ini tentunya memiliki keterbatasan yang dapat memengaruhi kualitas hasil penelitian, di antaranya pengambilan sampel terbatas pada perusahaan manufaktur yang terdaftar pada Bursa Efek Indonesia (BEI) dalam rentang tahun 2016-2018. Selain itu ternyata diketahui bahwa mayoritas perusahaan manufaktur di BEI pada periode 2016-2018 tidak memiliki pos intangible asset di dalam laporan keuangannya sehingga pengujian tidak dapat dilakukan secara menyeluruh. Tentunya semakin besar rentang waktu observasi dan jumlah sampel observasi maka semakin besar pula data yang dapat dianalisa sehingga akan menghasilkan kesimpulan yang lebih komprehensif.

Berdasarkan penelitian ini, penulis memberikan beberapa saran baik kepada otoritas perpajakan dan untuk penelitian selanjutnya. Penulis merasa perlu dipertimbangkan pembentukan clustering sektor industry, dalam praktek penggalian potensi, dimana terhadap industri manufaktur perlu ditekankan perhatian lebih kepada pos keuangan berupa nilai fixed asset, sales growth serta manfaat pajak tangguhan (deferred tax income) yang berpotensi lebih besar menyumbang indikasi terjadinya tax avoidance yang dilakukan perusahaan. Sementara pada sector industri lainnya dikembangkan penekanan pada beberapa pos tertentu yang berdasarkan hasil penelitian lain menyumbang indikasi adanya upaya tax avoidance yang dilakukan perusahaan. Kemudian perluasan sasaran observasi dimana penggunaan sampel tidak hanya berpaku pada perusahaan manufaktur melainkan juga pada sektor keuangan dan sektor digital yang sedang berkembang pada saat ini. Dengan demikian hasil penelitian dirasa dapat lebih menyeluruh.

\section{Daftar Pustaka}

Acquah, P. H. I. L. O. M. I. N. A. (2017). Transfer Pricing, Earnings Management, And Tax Avoidance (Doctoral dissertation, University of Ghana).

Annuar, H. A., Salihu, I. A., \& Obid, S. N. S. (2014). Corporate Ownership, Governance and Tax Avoidance: An Interactive Effects. Procedia - Social and Behavioral Sciences, 164(August), 150160.

https://doi.org/10.1016/j.sbspro.2014.11. 063.

Anouar, D., \& Houria, Z. (2017). The determinants of tax avoidance within corporate groups: Evidence from Morocca mics, Finance and Management Sciences, 5(1), 57. Https://Doi.Org/10.11648/J.Ijefm.201705 01.15 .

Barker, J., Asare, K., \& Brickman, S. (2017). Transfer pricing as a vehicle in corporate tax avoidance. Journal of Applied Business Research (JABR), 33(1), 9-16.

Blaylock, B., Shevlin, T., \& Wilson, R. J. (2012). Tax avoidance, large positive temporary book-tax differences, and earnings persistence. The Accounting Review, 87(1), 91-120.

Desai, M. A., \& Dharmapala, D. (2009). 
Corporate tax avoidance and firm value. The review of Economics and Statistics, 91(3), 537-546.

Desai, M. A., \& Dharmapala, D. (2009). Earnings management, corporate tax shelters, and book-tax alignment. National Tax Journal, 169186.

Dridi, W., \& Adel, B. (2016). Book-Tax Differences and the Persistence of Earnings and Accruals: Tunisian Evidence. Asian Social Science, 12(6), 193-202.

Formigoni, H., Antunes, M. T. P., \& Paulo, E. (2009). Difference between Accounting Profit and Taxable Profit: An Analysis of Management of Accounting Results and Tax Management at Brazilian Public Companies. Brazilian Business Review, 6(1), 42-58. https://doi.org/10.15728/bbr.2009.6.1.3.

Goncharov, I., \& Zimmermann, J. (2005). Earnings management when incentives compete: the role of tax accounting in Russia. Available at SSRN 622640.

Hanlon, M., \& Slemrod, J. (2009). What does tax aggressiveness signal? Evidence from stock price reactions to news about tax shelter involvement. Journal of Public Economics, 93(1-2), 126-141.

Höglund, H., \& Sundvik, D. (2016). Financial reporting quality and outsourcing of accounting tasks: Evidence from small private firms. Advances in accounting, 35, 125-134.

Indonesia, I. A. (2008). Pernyataan Standar Akuntansi Keuangan (Psak) No. 16 Aset Tetap, 16(14), 1-11.

Indonesia, I. A. (2010). Pernyataan Standar Akuntansi Keuangan (Psak) No. 19 Aset Tidak Berwujud, 19(19).

Indonesia, I. A. (2018). Pernyataan Standar Akuntansi Keuangan (Psak) No. 46 Pajak Penghasilan. November.

Inger, K. K. (2014). Relative valuation of alternative methods of tax avoidance. The Journal of the American Taxation Association, 36(1), 27-55.
Jensen, M. C., \& Meckling, W. H. (1976). Theory of the firm: Managerial behavior, agency costs and ownership structure. Journal of financial economics, 3(4), 305-360.

Kim, J. H., \& Im, C. C. (2017). The study on the effect and determinants of small-and medium-sized entities conducting tax avoidance. Journal of Applied Business Research (JABR), 33(2), 375-390.

Kim, W. J., \& Jang, G. B. (2018). Relationship between Tax Avoidance and Key Financial Indicators in Korea's Construction Waste Disposal Industry. Academy of Accounting and Financial Studies Journal, 22(3), 1-12.

Kurniasih, L., \& Suranta, S. (2017). Earnings Management, Corporate Governance and Tax Avoidance: The Case in Indonesia. Corporate Governance and Tax Avoidance: The Case in Indonesia (December 9, 2017). J. Fin. Bank. Review, 2(4), 28-35.

Lanis, R., \& Richardson, G. (2012). Corporate social responsibility and tax aggressiveness: An empirical analysis. Journal of Accounting and Public Policy, 31(1), 86-108.

Lee, H. A. (2016). The Usefulness Of The Tax Avoidance Proxy: Evidence From Korea. Journal of Applied Business Research (JABR), 32(2), 607-620.

Lestari, R. D., \& Rachmawati, S. (2018). Perencanaan Pajak dan Book Tax Differences terhadap Persistensi Laba dengan Variabel Moderating Kualitas Laba. INDONESIAN JOURNAL OF ACCOUNTING AND GOVERNANCE, 2(2), 69-89.

Lin, K. Z., Mills, L. F., \& Zhang, F. (2014). Public versus private firm responses to the tax rate reduction in China. The Journal of the American Taxation Association, 36(1), 137-163.

Lisowsky, P. (2008). Seeking shelter: Empirically modeling tax shelters and examining their link to the contingent tax liability reserve (Doctoral dissertation, Boston University). 
Listokin, Y., \& Schizer, D. M. (2012). I like to pay taxes: Taxpayer support for government spending and the efficiency of the tax system. Tax L. Rev., 66, 179.

Meiza, R. (2015). Pengaruh Karakteristik Good Corporate Governance Dan Deferred Tax Expense Terhadap Tax Avoidance (Studi Empiris pada Perusahaan Manufaktur yang Listing di BEI tahun 2010-2013). Jurnal Akuntansi, 3(1).

Martinez, A. L., \& Bassetti, M. (2016). Firm Life Cycle, Book-Tax Differences and Earnings Persistence. Revista de Educação e Pesquisa em Contabilidade, 10(2).

Martinez, A. L., de Souza, T. B. T., \& MonteMor, D. S. (2016). Book-tax differences, earnings persistence and tax planning before and after the adoption of IFRS in Brazil. Advances in Scientific and Applied Accounting, 9(2), 162-180.

Merle, R., Al-Gamrh, B., \& Ahsan, T. (2019). Tax havens and transfer pricing intensity: Evidence from the French CAC-40 listed firms. Cogent Business \& Management, 6(1), 1647918.

Nomor, U. U. R. I. (36). tahun 2008 tentang Perubahan Keempat atas Undang-Undang Nomor 7 tahun 1983 Tentang Pajak Penghasilan.(2008). Jakarta: Sekretariat Negara Republik Indonesia.

Pajak, D. J. (2018). Surat Edaran Direktur Jenderal Pajak Nomor SE-15/Pj/2018 Tentang Kebijakan Pemeriksaan.

Permata, A. D., Nurlaela, S., \& Wahyuningsih, E. M. (2018). Pengaruh Size, Age, Profitability, Leverage Dan Sales Growth Terhadap Tax Avoidance. Jurnal Akuntansi Dan Pajak, 19(1), 10. Https://Doi.Org/10.29040/Jap.V19i1.171

Persada, A. E., \& Martani, D. (2010). Analisis Faktor yang Mempengaruhi Book Tax Gap dan Pengaruhnya Terhadap Persistensi Laba. Jurnal Akuntansi dan Keuangan Indonesia, 7(2), 205-221.

Plesko, G. A. (2004). Corporate tax avoidance and the properties of corporate earnings. National Tax Journal, 729-737.
Purba, D. M. (2018). The Influence of Earnings Management, Audit Quality and CEO Duality on Tax Avoidance. The Accounting Journal of Binaniaga, 3(01), 25-38.

Rachmawati, N. A., \& Martani, D. (2014). Pengaruh large positive abnormal booktax differences terhadap persistensi laba. Jurnal Akuntansi dan Keuangan Indonesia, 11(2), 120-137.

Sekaran, U. dan Bougie, Roger. 2013. Research Methods for Business.

Stubben, S. R. (2010). Discretionary revenues as a measure of earnings management. The accounting review, 85(2), 695-717.

Sugiyono. (2016). Metedologi Penelitian Kualitatif, Kuantitatif dan $R \& D$. Alfabeta. Bandung.

Sundvik, D. (2017). A Review Of Earnings Management In Private Firms In Response To Tax Rate Changes. Nordic Tax Journal, 2017(1), 151-161. Https://Doi.Org/10.1515/Ntaxj-20170011

Susilowati, A., Dewi, R. R., \& Wijayanti, A. (2020). Faktor-Faktor Yang Mempengaruhi Tax Avoidance. Jurnal Ilmiah Universitas Batanghari Jambi, 20(1), 131. https://doi.org/10.33087/Jiubj.V20i1.808

Suyono, E. (2017). Berbagai model pengukuran earning management: mana yang paling akurat. Sustainable Competitive Advantage (SCA), 7(1).

Tang, T., \& Firth, M. (2011). Can book-tax differences capture earnings management and tax management? Empirical evidence from China. The International Journal of Accounting, 46(2), 175-204.

Tang, T. Y. (2019). The value implications of tax avoidance across countries. Journal of Accounting, Auditing \& Finance, 34(4), 615-638.

Https://Doi.Org/10.1177/0148558x17742 821

Tang, T. Y. (2015). Does book-tax conformity deter opportunistic book and tax reporting? An international 
Dimas Prihandana Jati, Etty Murwaningsari: Hubungan Book Tax Differences terhadap Tax Avoidance dengan Manajemen Laba sebagai Variabel Moderasi

analysis. European

Accounting

Review, 24(3), 441-469. 